\title{
A NEW STIGMODERA FROM WESTERN AUSTRALIA.
}

\author{
By \\ H. J. Carter, B.A., \\ Honorary Entomologist, Australian Museum.
}

(Figure 1.)

Stigmodera (Castiarina) flavocoerulea, n. sp.

Oblong. Head, prothorax, scutellum, underside, appendages and elytral apex (narrowly) brilliant blue: elytra otherwise (save for a narrow blue basal border) pale straw colour.

Head widely sulcate, finely punctate.

Prothorax, apex and base lightly bisinuate, the latter nearly twice as wide as former, with a small central fovea and minute basal excisions, all angles wide: sides widely and evenly rounded, without sinuation: disk with a narrow, arcuate ridge at apical third, containing some laevigate spaces; otherwise finely, evenly punctate, the punctures round and moderately close, much finer in middle, without signs of a medial line.

Scutellum elongate, cordiform: sulcate in middle.

Elytra widened at shoulders, widely and lightly constricted behind them; not much narrowed behind, apices sharply bispinose, external spine the longer, subapical margins serrulate: striate-punctate, the striae rather wide, intervals very lightly convex, finely and irregularly punctate. Underside glabrous, nitid, with fine, shallow punctures.

Dim. $16 \times 6 \mathrm{~mm}$.

Hab.-Western Australia: Wurarga (Mr. A. Goerling).

A single example sent is so distinctly separated from its allies as to deserve description. In general form and pattern it most resembles S. luteipennis L. \& G., from which it differs in colour, wider and more convex prothorax and strongly spined apices.

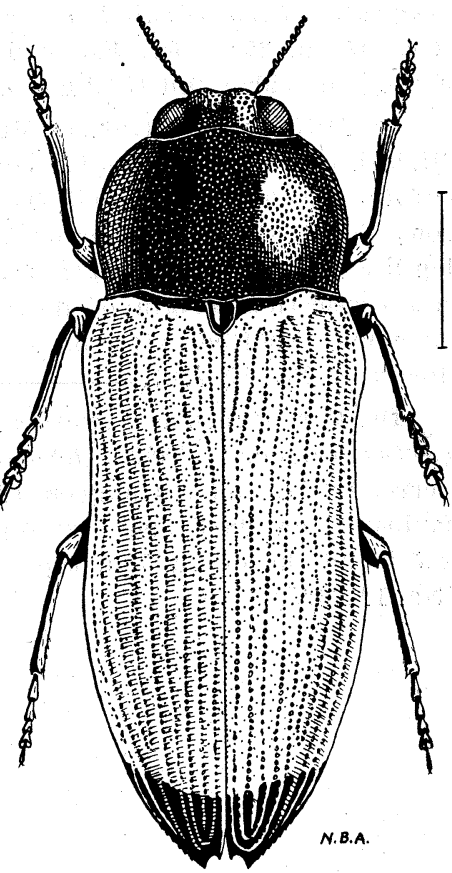

Fig. 1.-Stigmodera (Castiarina) flavocoerulea, n. sp. In colour its upper surface comes near some of the pale varieties of S. yarelli L. \& G. (without, however, the yellow border of prothorax). Holotype presented to the Australian Museum. 